\title{
Implementasi Model Pembelajaran Think Pair Share dalam Meningkatkan Hasil Belajar Siswa Kelas III SD pada Mata Pelajaran Pendidikan Agama Kristen
}

\author{
Riyati Hutauruk, S.Pd.K ${ }^{1^{*}}$ \\ ${ }^{1}$ Guru Pendidikan Agama Kristen, SD Negeri 153079 Pinangsori 6, \\ Kecamatan Pinangsori, Kabupaten Tapanuli Tengah \\ *riyatihutauruk@gmail.com
}

\begin{abstract}
Abstrak
Penelitian ini bertujuan untuk mengetahui peningkatan hasil belajar siswa sekolah dasar pada mata pelajaran Pendidikan Agama Kristen setelah diterapkan model pembelajaran Think-Pair-Share selama kegiatan belajar mengajar pada Siswa Sekolah Dasar. Jenis penelitian yang digunakan adalah Penelitian Tindakan Kelas (PTK). Subjek penelitian adalah siswa kelas III SD Negeri 153075 Pinangsori 4 dengan jumlah siswa sebanyak 14 orang.

Hasil penelitian menunjukkan bahwa hasil belajar kognitif siswa meningkat sesuai dengan ketuntasan klasikal. Selain itu, afektif siswa juga meningkat di setiap indikatornya dan sesuai dengan nilai rata-rata proporsi ketuntasan dengan nilai A (sangat baik). Lebih lanjut, psikomotorik siswa meningkat pada setiap indikatornya dan sesuai dengan nilai rata-rata proporsi ketuntasan dengan nilai A (sangat baik). Peningkatan ketiga aspek tersebut membuktikan bahwa hasil belajar siswa meningkat melalui penerapan model pembeljajaran Think-PairShare.
\end{abstract}

Kata Kunci: Think-Pair-Share, Pendidikan Agama Kristen, Siswa SD

\begin{abstract}
This study aims to determine the improvement of elementary students' learning achievements on Christian Religious Education after the implementation of the Think-Pair-Share learning model during teaching and learning activities. The research method used was Classroom Action Research (CAT). Subjects in this study were third grade elementary students, at the Public School 153075 Pinangsori 4, who were fourteen students.

The results showed that elementry students' cognitive learning achievements improved according to classical completeness. In addition, elementry students' attitudes also increased on each indicator and it was relevan to the average value of the completeness proportion with an A (very good). Furthermore, elementry students' psychomotor increased on each indicator and it was relevant to the average value of completeness with an A (very good). The improvemnet of those three aspects proves that elementry students' learning achievements increased through the implementation of the Think-Pair-Share learning model.
\end{abstract}

Keywords: Think-Pair-Share, Christian Religious Education, Elementry Students 


\section{PENDAHULUAN}

Pendidikan agama dimaksud untuk membentuk siswa menjadi manusia yang beriman dan bertaqwa kepada Tuhan Yang Maha Esa. Melalui pendidikan agama diharapkan kerohanian peserta didik dapat meningkat yang mencakup akhlak mulia, seperti etika, budi pekerti, dan moral. Secara khusus, Pendidikan Agama Kristen (PAK) memiliki tujuan untuk menanamkan world-view yang berpusat pada Tuhan serta bagaimana mereka berhubungan dengan individu Kristen lainnya (Purba, 2017:59). Oleh karena itu, peningkatan potensi spiritual PAK didukung dengan adanya pengenalan, pemahaman tenteang nilai-nilai kekristenan dalam kehidupan individual maupun kolektif kemasyarakatan. Namun, Pendidikan Agama Kristen di sekolah masih cenderung dibuat seperti pembelajaran bersifat hafalan. Bagi siswa, pendidikan agama Kristen yang demikian menjadi beban. Akibatnya, siswa pun menjadi kurang bersemangat dalam mengikuti pelajaran agama Kristen di sekolah.

Berdasarkan pengalaman peneliti selama mengajar di kelas III SD Negeri 153075 Pinangsori 4, pelajaran agama Kristen adalah pelajaran yang kurang diminati oleh siswa karena pelajaran agama Kristen dianggap siswa sebagai pelajaran yang membosankan. Kebosanan siswa timbu karena siswa menganggap bahwa belajar Agama Kristen penuh dengan hafalan. Sehingga, setiap pelajaran agama Kristen siswa sering tidak memperhatikan guru saat menjelaskan materi pelajaran, sebaliknya siswa sering melakukan kegiatan yang di luar pelajaran seperti menggambar, bercerita, main dengan teman satu bangku, dan tidur-tiduran. Hal ini mengakibatkan sebagian besar hasil belajar siswa mendapatkan nilai di bawah KKM.

Selanjutnya, guru masih melakukan pembelajaran dengan cara konvensional, yaitu ceramah dan siswa hanya pasif mendengar. Kondisi tersebut mengakibatkan siswa tidak mempersiapkan diri karena sudah menjadi kewajiban bagi guru menjelaskan materi ajar dan tugas siswa yakni mendengar. Akibatnya, siswa malas belajar di rumah, siswa tidak berpikir secara kritis, dan siswa tidak kreatif. Beranjak dari stituasi tersebut, peneliti menyadari bahwa peneliti harus mengubah cara mengajar atau model pembelajaran apabila ingin mendapat hasil hasil belajar siswa yang maksimal dan memuaskan. Oleh karena itu, peneliti perlu memberikan inovasi pembelajaran terhadap cara peneliti mengajar. Inovasi yang dilakukan yakni dengan mengubah cara mengajar di dalam kelas dari konvensional menjadi kooperatif. Adapun model pembelajaran yang diimplementasikan adalah Think-Pair-Share. Model Pembelajaran Think-Pair-Share sangat bermanfaat bagi guru dalam mengajarkan materi pembelajaran kepada siswa. 
Think Pair Share (TPS) merupakan jenis pembelajaran kooperatif yang dirancang dalam bentuk diskusi yang dapat meningkatkan kemampuan berpikir dan keterampilan berkomunikasi siswa, serta mendorong partisipasi para siswa di dalam kelas (Nurnawati, 2012:2). Menurut Suparno (2007:137) dengan adanya Think diharapkan siswa bisa berpikir sendiri-sendiri atau menjawab soal yang diberikan oleh guru. Pair, siswa berdiskusi secara berpasangan dan akhirnya Share, siswa berbagi hasil diskusi dengan seluruh siswa satu kelas kemudian memadukannya serta membuat kesimpulan bersama. Hal ini dimaksudkan supaya siswa lebih terbuka dengan teman sebayanya dalam memecahkan permasalahan yang mereka hadapi. Tahapan pair, siswa diminta untuk berpasangan dan mendiskusikan apa yang sudah dipikirkan.

Secara umum, dapat diberikan penekanan pada permasalahan yang ada dalam penelitian ini yang terdiri dari (1) Minat belajar siswa terhadap Mata Pelajaran Agama Kristen rendah; (2) Hasil belajar siswa pada Mata Pelajaran Agama Kristen cukup mengecewakan; (3) Kurangnya pengembangan kemampuan berpikir siswa, sehingga aktivitas belajar siswa kurang. Siswa cenderung pasif selama pembelajaran; (4) Penyampaian materi yang monoton dan metode yang tidak efektif, peneliti (guru) cenderung menggunakan metode konvensional; dan (5) Kurangnya fasilitas penunjang pembelajaran dan guru kurang dalam pemanfaatan media.

Permasalahan dalam penelitian ini dirumuskan menjadi tiga poin penting, yaitu: (1) bagaimanakah kognitif siswa kelas III SD pada mata pelajaran Pendidikan Agama Kristen setelah diterapkan model pembelajaran Think Pair Share? (2) bagaimanakah afektif siswa kelas III SD pada mata pelajaran Pendidikan Agama Kristen setelah diterapkan model pembelajaran Think Pair?; dan (3) bagaimanakah psikomotorik siswa kelas III SD pada mata pelajaran Pendidikan Agama Kristen setelah diterapkan model pembelajaran Think Pair Share? Setiap penelitian sudah pasti mempunyai sasaran yang ingin dicapai. Tujuan merupakan titik tolak untuk melakukan kegiatan dan dari kegiatan tersebut akan diukur tingkat keberhasilannya. Adapun tujuan penelitian ini adalah: (1) untuk mengetahui kognitif siswa kelas III SD pada mata pelajaran Pendidikan Agama Kristen setelah diterapkan model pembelajaran Think Pair Share; (2) untuk mengetahui afektif siswa kelas III SD pada mata pelajaran Pendidikan Agama Kristen setelah diterapkan model pembelajaran Think Pair Share; dan (3) untuk mengetahui psikomotorik siswa kelas III SD pada mata pelajaran Pendidikan Agama Kristen setelah diterapkan model pembelajaran Think Pair Share. 
Ada beberapa manfaat yang didapatkan dari penelitian ini, yaitu: (1) sebagai bahan masukan yang berarti bagi guru kelas dalam mengajarkan materi pokok pemeliharaan Allah pada Mata Pelajaran Agama Kristendi sekolah; (2) Meningkatkan aktivitas, dan memperbaiki hasil belajar siswa; (3) Menambah pengetahuan peneliti tentang model pembelajaran Think Pair Share dan juga dampaknya jika diterapkan selama pembelajaran; dan (4) Sebagai bahan pertimbangan bagi peneliti berikutnya mengenai penggunaan model pembelajaran Think Pair Share sebagai salah satu rancangan pengajaran. Oleh karena itu, berdasarkan latar belakang masalah dan kontribusi seperti yang telah diuraikan di atas, penelitian ini mengkaji tentang implementasi model pembelajaran think pair share dalam meningkatkan hasil belajar siswa kelas III SD pada mata pelajaran Pendidikan Agama Kristen.

\section{METODE PENELITIAN}

Desain penelitian ini adalah Penelitian Tindakan Kelas (Classroom Action Research). Penelitian Tindakan Kelas merupakan penelitian yang mengombinasikan prosedur penelitian dengan tindakan substantif, suatu tindakan yang dilakukan dalam disiplin inkuiri, atau suatu usaha seseorang memahami apa yang sedang terjadi, sambil terlibat dalam sebuah prosedur perbaikan dan perubahan (Hopkins, 1993:44). Arikunto dan Suhardjono (2006) mengatakan bahwa Penelitian Tindakan Kelas adalah penelitian yang dilakukan oleh guru atau bekerja sama dengan peneliti lainnya (atau dilakukan sendiri oleh guru yang bertindak sebagai peneliti) di kelas atau di sekolah tempat dia mengajar dengan penekanan pada penyempurnaan atau peningkatan proses dan praktis pembelajaran.

Penelitian Tindakan Kelas ini dilakukan di SD Negeri 153075 Pinangsori 4 Kecamatan Pinangsori Kabupaten Tapanuli Tengah. Penelitian dimulai pada semester Ganjil yang dimuali dari September sampai November pada Tahun Pelajaran 2017/2018. Subjek penelitian ini melibatkan siswa kelas III dengan jumlah 14 orang. Data dalam penelitian dikumpulkan melalui: (a) Tes Hasil Belajar yang terdiri dari 10 soal dalam bentuk pilihan berganda; (b) Lembar Observasi Sikap Belajar Siswa untuk mengamati sikap belajar siswa pada kelompok belajar yang telah dibentuk guru. Pengamatan dilakukan secara rahasia dengan demikian seluruh kelompok belajar akan merasa sikap belajarnya sedang diamati oleh pengamat. Indikator pada lembar sikap siswa ini terdiri dari 5 aspek yaitu: sikap kejujuran, disiplin, tanggung jawab, ketelitian, dan kerjasama; (c) Lembar Observasi Psikomotorik Siswa digunakan pada saat kegiatan 
belajar mengajar untuk mengetahui peningkatan keterampilan siswa dalam mengelola informasi belajar dalam kelompok. Indikator pada lembar keterampilan siswa ini terdiri dari 5 aspek yaitu: mengamati, mengumpulkan data, menganalisis, menginterpretasi dan yang terakhir mengkomunikasikan hasil.

Langkah-langkah Penelitian Tindakan Kelas terdiri dari tahap persiapan, diagnostik, perencanaan tindakan kelas untuk memecahkan masalah, dan teurapeutik. Prosedur Penelitian Tindakan Kelas pada setiap siklus, yakni: (1) perencanaan (planning), (2) pelaksanaan tindakan kelas (action), (3) observasi (observation) dan refleksi (reflection) serta revisi rencana (Hopkins, 1993: 68).

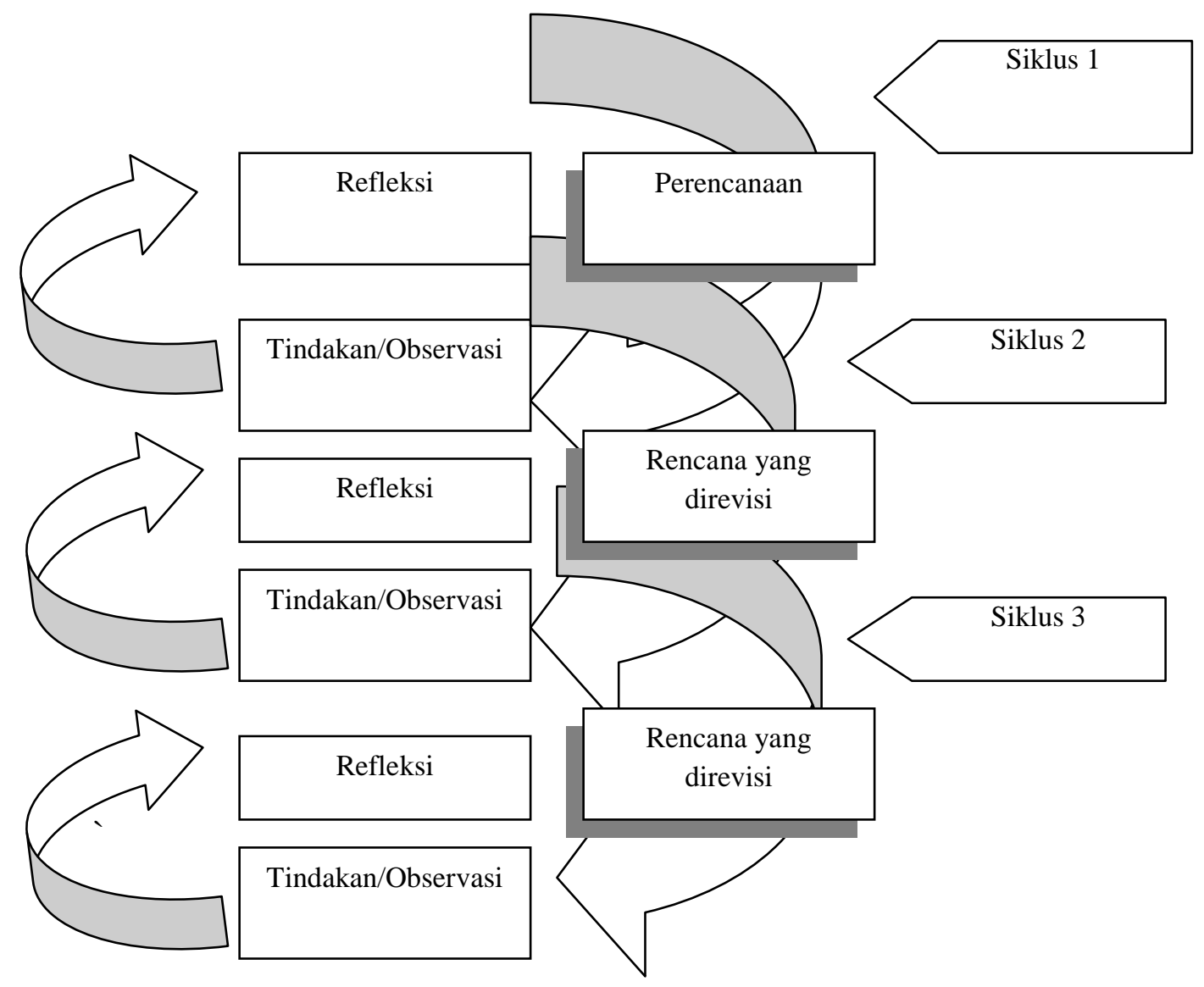

Gambar 1. Alur Penelitian Tindakan Kelas

\section{Perencanaan penelitian}

Perencanaan penelitian berkaitan dengan identifikasi, analisis, dan rencana penelitian. Kegiatan ini dilakukan dengan cara orientasi lapangan dan observasi, yaitu: (a) Melaksanakan dialog dengan tutor, sesama guru tentang permasalahan yang dihadapi berkaitan dengan materi dan pembelajaran Agama Kristen dalam praktik sehari-hari; (b) Observasi kegiatan pembelajaran Agama Kristen di Kelas III SD. 


\section{Pelaksanaan Tindakan Kelas}

Siklus 1 terdiri dari: (a) Skenario pembelajaran dan alat evaluasi pembelajaran yang telah dibuat oleh guru tentang standar kompetensi "pemeliharaan Allah" untuk dianalisis bersama, dan selanjutnya diubah atau ditambah sesuai dengan model pembelajaran kooperatif tipe think-pair-share, sehingga rencana pembelajaran merupakan hasil kolaborasi antara tutor, peneliti dan sesama peneliti dan guru; (b) Membuat instrumen penelitian lembar observasi afektif dan psikomotorik siswa dalam proses pembelajaran menerapkan model pembelajaran kooperatif Tipe Think-pairShare; (c)Pelaksanaan Tindakan dan Observasi (Action/Observation). Pelaksanaan Tindakan pembelajaran ke-1 dan ke-2 sesuai dengan skenario oleh peneliti sebagai guru di Kelas III. Selama proses pembelajaran dilakukan observasi oleh guru sejawat (kolaborator) untuk mengamati Afektif dan Psikomotorik siswa. Diakhir siklus dilakukan pula tes penguasaan konsep Agama Kristen siswa sesuai dengan indikator materi yang sudah dijelaskan; (d) Refleksi (Reflective). kegiatan refleksi dilakukan oleh peneliti dengan kolaborator berdasarkan hasil observasi, evaluasi hasil pembelajaran berupa penguasaan konsep Agama Kristen, dan meminta masukan dari siswa tentang proses pembelajaran Agama Kristen dengan model pembelajaran kooperatif tipe Thinkpair-Share. Dari hasil refleksi kemudian peneliti berkolaborasi dengan Pengamat di SD Negeri 153075 Pinangsori 4, memperbaiki dan menguatkan rencana tindakan siklus II.

Siklus 2 terdiri dari: (a) Perencanaan Tindakan. Berdasarkan hasil refleksi terhadap proses pembelajaran pada siklus I, maka pada siklus II disusun skenario pembelajaran model pembelajaran kooperatif tipe think-pair-share yang merupakan perbaikan dari siklus I beserta alat evaluasi pembelajarannya; (b) Pelaksanaan Tindakan dan Observasi (Action/observation) dilaksanakan sesuai pada tindakan pembelajaran ke3 dan ke-4 berdasarkan skenario pembelajaran model pembelajaran kooperatif tipe Think-pair-Share oleh peneliti sebagai guru Agama Kristen dilakukan observasi oleh observer untuk mengamati Afektif dan Psikomotorik siswa. Diakhir siklus dilakukan tes penguasaan konsep Agama Kristen siswa sesuai dengan materi yang diajarkan pada siklus II; (c) Refleksi (Reflective), setelah kegiatan pembelajaran siklus II dilaksanakan, dilanjutkan dengan kegiatan refleksi oleh peneliti berkolaborasi dengan Pengamat. Berdasarkan hasil observasi dari evaluasi hasil pembelajaran berupa penguasaan konsep Agama Kristen siswa dan masukan dari siswa tentang proses pembelajaran, maka hasil pembelajaran ditelaah ketuntasannya berkaitan dengan penguasaan konsep Agama Kristen siswa. 


\section{Teknik Analisis Data}

Analisis data dilakukan secara kualitatif selama penelitian berlangsung, dalam arti sejak pengumpulan informasi dilakukan, maka sejak itulah analisis terhadap data yang ditemukan dilakukan pula. Data atau informasi dari lapangan yang diperoleh melalui wawancara ataupun observasi atau studi dokumentasi dideskripsikan kemudian diseleki pada hal-hal yang bersifat urgen untuk ditayangkan ke dalam bentuk bagan atau tabel catatan lapangan. Analisis data kuantitatif dilakukan terhadap penguasaan konsep Agama Kristen oleh siswa, dengan cara membandingkan penguasaan konsep sebelum tindakan dilakukan dengan penguasaan konsep setelah Siklus I dan II.

Penghitungan ketuntasan belajar siswa dalam hal penguasaan konsep ditentukan melalui penguasaan terhadap konsep Agama Kristen yang mencapai 85\% dalam kelas.

1. Untuk menilai penguasaan konsep siswa melalui tes formatif yang diperoleh dari penjumlahan nilai yang diperoleh siswa, yang selanjutnya dibagi dengan jumlah siswa yang ada di kelas tersebut sehingga diperoleh rata-rata tes formatif. Berikut rumus yang dapar digunakan untuk menganalisis data:

$$
\begin{aligned}
\bar{X}=\frac{\sum X}{\sum N} & \\
\text { Keteerangan: } \bar{X} & =\text { Nilai rata-rata } \\
\Sigma \mathrm{X} & =\text { Jumlah semua nilai siswa } \\
\Sigma \mathrm{N} & =\text { Jumlah siswa }
\end{aligned}
$$

2. Untuk ketuntasan penguasaan konsep secara perorangan dan secara klasikal. Ketuntasan seorang siswa dapat diketeahui dari penguasaan konsepnya dengan hasil tes mencapai KKM, yaitu 70, dan kelas disebut tuntas penguasaan konsepnya apabila di kelas tersebut terdapat $85 \%$ yang telah mencapai daya serap lebih dari atau sama dengan KKM.Untuk menghitung persentase ketuntasan belajar digunakan rumus sebagai berikut:

$$
P=\frac{\sum \text { Siswa yang tuntas penguasaan konsepnya }}{\sum \text { Seluruh Siswa }} \times 100 \%
$$

Penilaian:

a. Penilaian psikomotorik dan sikap siswa dilakukan dengan memberi skor (1-4) pada kolom tersedia sesuai fakta yang diamati. Arikunto (2002:122) membuat kategori kemampuan psikomotor berkaitan dengan kemampuan yang menyangkut kegiatan otot sehingga menyebabkan geraknya tubuh atau bagian-bagiannya. 
b. Rumus untuk menentukan nilai psikomotoik dan afektif peserta didik adalah :

$$
\% \text { Proporsi }=\frac{\text { jumlah skor yang diperoleh }}{\text { jumlah skor ideal }} \times 100 \%
$$

(Sudjana, 2009)

c. Untuk menentukan taraf psikomotorik dan sikap peserta didik dengan nilai yang dicapai adalah dengan menggunakan standar/kriteria penilaian seperti pada Tabel 1:

Tabel 1. Kriteria dan Persentase Nilai Sikap dan Keterampilan

\begin{tabular}{lccc}
\hline \multicolumn{1}{c}{ Kriteria } & Persentase & Konversi & Huruf \\
\hline Sangat Baik & $85 \%-100 \%$ & $3,1-4$ & A \\
Baik & $75 \%-84 \%$ & $2,1-3$ & B \\
Cukup Baik & $65 \%-74 \%$ & $1,1-2$ & C \\
Kurang Baik & $55 \%-64 \%$ & $0-1$ & D \\
\hline
\end{tabular}

\section{HASIL PENELITIAN DAN PEMBAHASAN}

Pra Siklus. Tahap ini merupakan tahap pengambilan sampel awal dan melakukan observasi awal untuk melihat pengetahuan awal dan kondisi kekurangan. Selain itu, dari tahap ini, kelebihan siswa dalam proses pembelajaran dapat diambil suatu tindakan yang konstruktif untuk meningkatkan hasil belajar siswa, psikomotrik siswa serta kreativitas siswa. Hasil pengamatan mengenai pengetahuan awal siswa ditunjukkan pada Tabel 2.

\begin{tabular}{ccccc}
\multicolumn{6}{c}{ Tabel 2. Hasil Pre-tes Siswa } & & & \\
\hline Nilai & Frekuensi & Tuntas Individu & Tuntas Kelas & Nilai rata-rata \\
\hline 20 & 5 & - & - & \\
30 & 2 & - & - & \\
40 & 3 & - & - & 35,71 \\
50 & 2 & - & - & \\
60 & 2 & - & - & \\
Jumlah & 14 & & & \\
\hline
\end{tabular}

Berdasarkan Tabel 2 terlihat belum ada siswa yang dinyatakan tuntas secara individu maupun tuntas kelas. Ini berarti siswa secara keseluruhan tidak mempersiapkan diri dari rumah sebelum berangkat ke sekolah, terutama untuk materi baru.

\section{Siklus I}

Tahap Perencanaan Tindakan

Pada tahap ini peneliti mempersiapkan perangkat pembelajaran yang terdiri dari RPP 1 dan 2 untuk KBM 1 dan 2 serta formatif 1 dan alat-alat pengajaran yang mendukung. Sebelum memulai kegiatan penelitian, peneliti dan guru mitra (observer) berdiskusi untuk membuat skenario pembelajaran kooperatif tipe Think-Pair-Shared. 


\section{Tahap Kegiatan dan Pelaksanaan}

Alat pengumpul data adalah guru yang tergabung dalam kolabolator sebagai pengamat dengan alat format observasi. Sebelum masuk kelas dilakukan pengecekan terhadap kelengkapan dan kesiapan yaitu dilaksakanannya skenario pembelajaran yang telah direncanakan sesuai silabus dan skenario pembelajaran yang telah dibuat guru dengan masukan dari anggota peneliti lain.

Akhir siklus I dilakukan tes hasil belajar atau disebut formatif I dengan data pada Tabel 3. Dari data tersebut, guru berusaha memperbaiki proses dan hasil belajar serta psikomotorik siswa melalui model pembelajaran Think Pair Share. Berdasarkan hasil formatif 1, rata-rata nilai 45,71 dengan nilai tertinggi 80 diperoleh 3 siswa dan nilai terendah 20 diperoleh 4 siswa. Dengan demikian, ketuntasan klasikal mencapai 21,42\%. Siswa yang tuntas KKM pada siklus I sebanyak 3 orang siswa. Hasil belajar siswa yang diperoleh pada siklus I selama dua pertemuan ada pada Tabel 3.

\section{Tabel 3. Distribusi Hasil Formatif I}

\begin{tabular}{ccccc}
\hline Nilai & Frekuensi & Nilai rata-rata & Konversi & Keterangan \\
\hline 20 & 4 & & & \\
40 & 5 & & & \\
60 & 2 & 45,71 & 1,82 & $\mathrm{C}$ \\
80 & 3 & & & \\
Jumlah & 14 & & & \\
\hline
\end{tabular}

Data hasil formatif I dapat dilihat pada Gambar 2, dimana masih ada siswa yang memiliki nilai dibawah KKM.

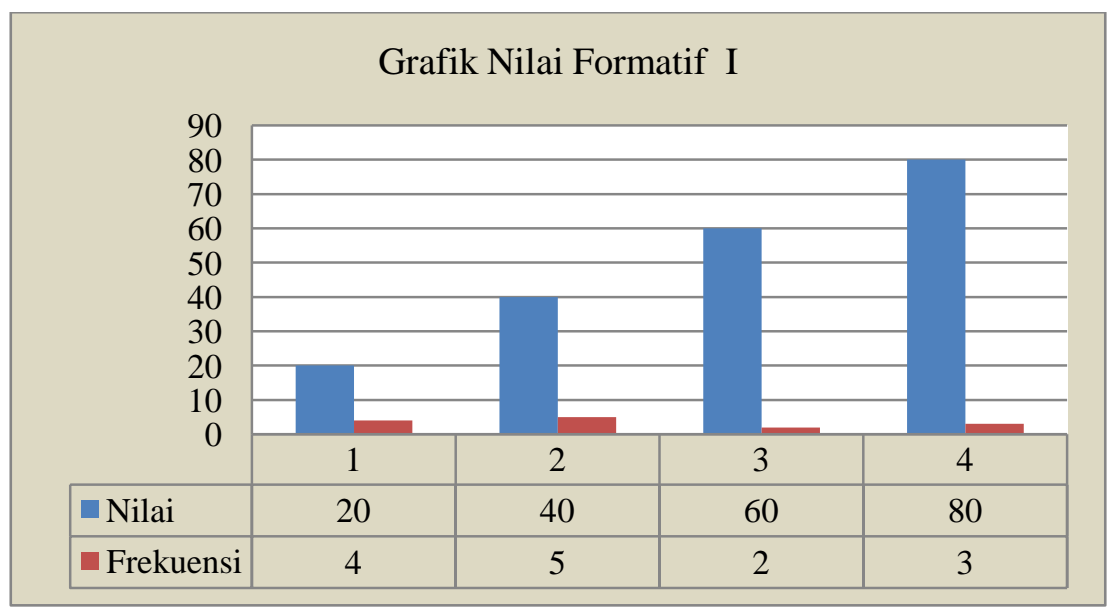

Gambar 2. Grafik Data Hasil Belajar Formatif I

Pada siklus I dilakukan pengamatan terhadap afektif siswa. Data afektif siswa pada siklus I disajikan pada Tabel 4. 
Tabel 4. Afektif Belajar Siswa Siklus I

\begin{tabular}{clccc}
\hline No & \multicolumn{1}{c}{ Afektif } & Skor & Persentase & Kategori \\
\hline 1 & Kejujuran & 38 & $59 \%$ & D \\
2 & Disiplin & 40 & $63 \%$ & D \\
3 & Ketelitian & 39 & $61 \%$ & D \\
4 & Saling Menghargai & 38 & $59 \%$ & D \\
5 & Kerjasama & 42 & $66 \%$ & C \\
$\quad$ Rata-rata Proporsi & & $62 \%$ & D \\
\hline
\end{tabular}

Dari data pada tabel 4 di atas kejujuran 59\%, disiplin 63\%, ketelitian 61\%, saling menghargai 59\% dan kerjasama $66 \%$ dengan rata-rata proporsi pada siklus I sebesar $62 \%$ yang berada dalam kategori nilai D. Data afektif siswa pada siklus I dapat disajikan dalam bentuk grafik pada Gambar 3.

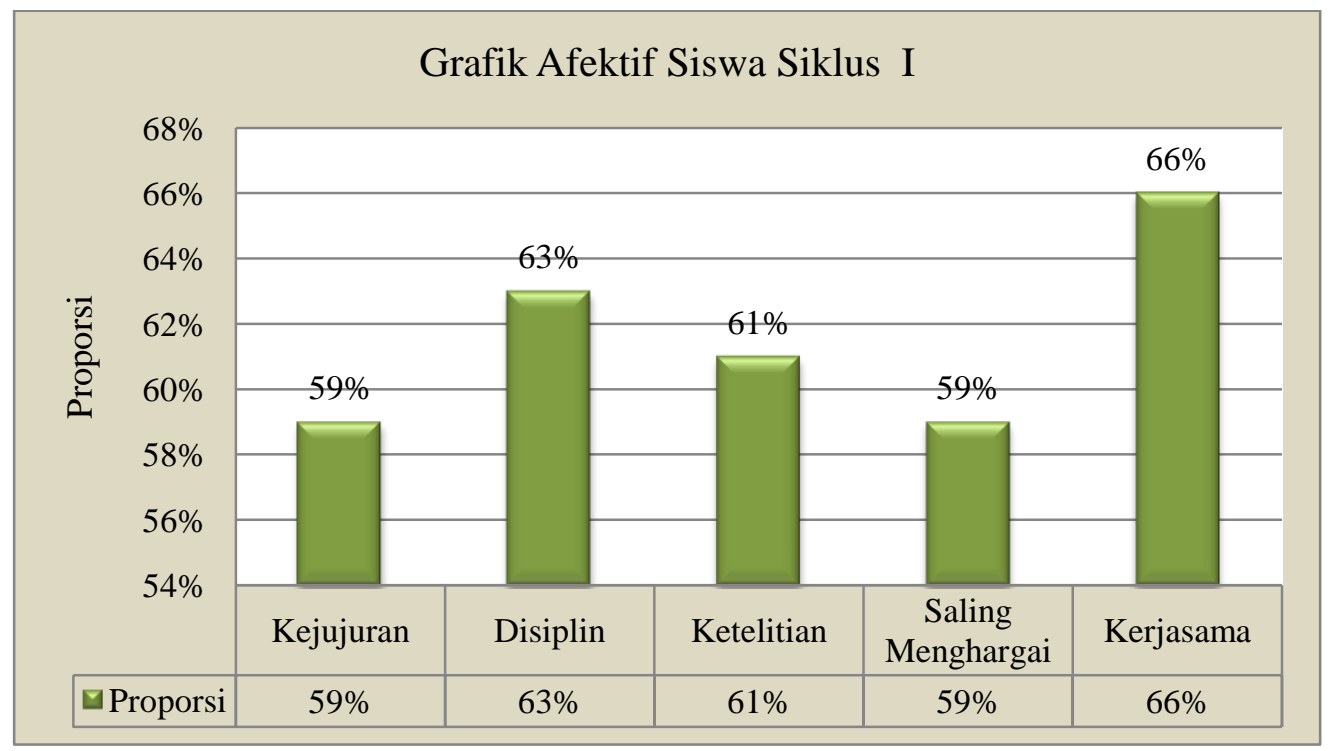

Gambar 3. Grafik Afektif Belajar Siswa Siklus I

Observasi juga dilakukan untuk melihat peningkatan psikomotorik siswa selama pembelajaran Pendidikan Agama Kristen di kelas. Data hasil Observasi keterampilan belajar siswa selama siklus I disajikan pada Tabel 5 berikut:

Tabel 5. Psikomotorik Siklus I

\begin{tabular}{clccc}
\hline No & \multicolumn{1}{c}{ Psikomotorik } & Skor & Persentase & Kategori \\
\hline 1 & Mengamati & 37 & $58 \%$ & $\mathrm{D}$ \\
2 & Menanya & 41 & $64 \%$ & $\mathrm{D}$ \\
3 & Mengumpulkan Data & 40 & $63 \%$ & $\mathrm{D}$ \\
4 & Mengasosiasi & 42 & $66 \%$ & $\mathrm{C}$ \\
5 & Mengkomunikasikan Hasil & 41 & $64 \%$ & $\mathrm{D}$ \\
& $\quad$ Rata-rata Proporsi & & $63 \%$ & $\mathrm{D}$ \\
\hline
\end{tabular}


Pada tabel 5 terlihat masih banyak siswa yang belum terampil dalam semua indikator. Keterampilan mengamati sebesar 58\%, menanya 64\%. Hal ini mengindikasikan siswa masih belum serius untuk mengikuti kegiatan pembelajaran. Keterampilan mengumpulkan data sebesar $63 \%$ dan mengaosiasi sebesar $66 \%$, Data tersebut menunjukkan siswa belum aktif dan fokus dalam melakukan diskusi dengan kelompoknya. Keterampilan mengomunikasikan hasil sebesar 64\%, dengan rata-rata proporsi keterampilan belajar siswa pada siklus I sebesar $63 \%$ yang berada dalam kategori nilai D. Data keterampilan siswa pada siklus I disajikan pada Gambar 4.

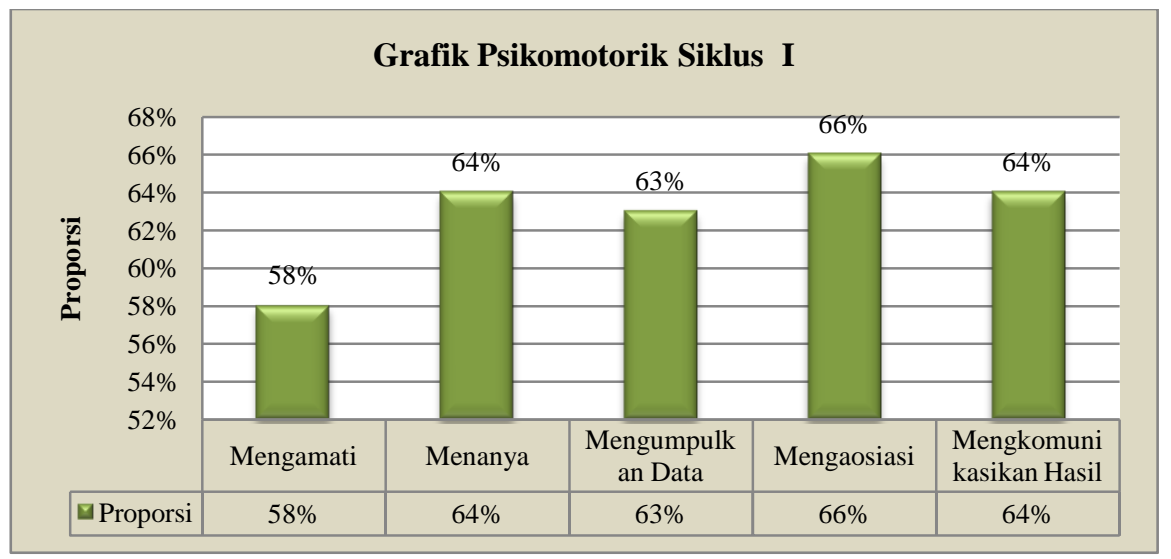

Gambar 4. Grafik Psikomotorik Siklus I

\section{Refleksi Pelaksanaan Tindakan}

Pada tahap ini akan dikaji apa yang telah terlaksana dengan baik maupun yang masih kurang baik dalam proses belajar mengajar dengan penerapan Model Pembelajaran Kooperatif Tipe Think-Pair-Shared (TPS). Diakhir KBM Siklus I peneliti mendapati beberapa temuan, diantaranya: (1) Temuan positif terdiri dari: (a) Siswa sudah mulai aktif dalam bekerja bersama kelompoknya; (b) Hasil belajar siswa meningkat dari $0 \%$ tidak ada siswa yang tuntas secara individu dan tuntas secara klasika sebelumsiklus I, menjadi 21,4\% pada siklus I dengan rata - rata 45,71; (c)Siswa sudah mulai kondusip saat diskusi, karena ada LKS sebagai acuan diskusi. (2) Temuan negative, yaitu (a) Siswa masih banyak yang bermain-main dalam diskusi kelompok pada KBM 1, dan KBM 2; (b) Masih banyak siswa yang belum memahami perannya dalam kelompok; (c) Masih ada siswa yang kurang serius dalam belajar khususnya pada tahap think; (d) Masih banyak siswa yang kurang percaya diri sehingga mereka malu/takut membacakan hasil diskusinya di depan kelas; (e) Hasil belajar siswa pada siklus I belum mencapai ketuntasan meskipun terlihat ada perubahan hasil belajar siswa yang cukup signifikan; (f) Sulit apabila anggota pasangannya tidak aktif, maka akan mengakibatkan kelompok tersebut tidak aktif juga. 


\section{Revisi Pelaksanaan}

Pada siklus I guru telah menerapkan model pembelajaran kooperatif tipe ThinkPair-Share (TPS) dengan baik dan dilihat dari aktivitas siswa serta hasil belajar siswa pelaksanaan proses belajar mengajar sudah berjalan dengan baik. Memang masih diperlukan revisi, namun tidak terlalu banyak. Tetapi tetap peneliti harus memperhatikan tindakan selanjutnya untuk memaksimalkan hasil yang telah ada dengan tujuan agar pada pelaksanaan proses belajar mengajar selanjutnya penerapan model pembelajaran kooperatif tipe Think-Pair-Share (TPS) dapat meningkatkan proses belajar mengajar sehingga tujuan pembelajaran dapat tercapai.

Untuk meningkatkan proses pembelajaran dan aktivitas belajar siswa pada Siklus II, beberapa revisi/perbaikan pembelajaran dilakukan antara lain: (1) Lebih memberikan motivasi kepada siswa agar bersedia melakukan kegiatan diskusi kelompok tanpa harus ditunjuk atau dibujuk agar aktivitas individual siswa menyusut dan meningkat aktivitas positif seperti mengerjakan LKS, dan bertanya sesama teman; (2) Guru harus bertindak lebih tegas, agar siswa lebih tertib dalam mengikuti pelajaran dan siswa mau mengikuti setiap tahapan pembelajaran sesuai dengan model pembelajaran kooperatif tipe think-pair-share. Dan guru menjelaskan model belajar sesuai model pembelajaran kooperatif tipe think-pair-share di awal pembelajaran, agar siswa mengerti dan mengikuti setiap tahapan dengan baik.

\section{Siklus II}

\section{Perencanaan Tindakan}

Sebelum memulai Tindakan Siklus II, peneliti berdiskusi dengan guru mitra (kolabolator) untuk membuat skenario pembelajaran dengan model pembelajaran kooperatif tipe Think-Pair-Share (TPS). Selanjutnya, peneliti menelaah terlebih dahulu kompetensi dasar dan indikator materi yang akan disampaikan mengenai "pemeliharaan Allah" dengan memperhatikan hasil refleksi siklus I. Peneliti pun mempersiapkan perangkat pembelajaran yang terdiri dari RPP3 dan RPP 4, soal formatif II, dan alatalat pengajaran yang mendukung.

\section{Kegiatan dan Pelaksanaan}

Pelaksanaan kegiatan belajar mengajar siklus II dilaksanakan melibatkan sebanyak 14 orang. Proses belajar mengajar mengacu pada revisi siklus I. Akhir kegiatan belajar mengajar keempat dievaluasi melalui tes dengan hasil belajar ditunjukkan pada Tabel 6. 
Tabel 6 Distribusi Hasil Belajar Formatif II

\begin{tabular}{ccccc}
\hline Nilai & Frekuensi & Nilai rata-rata & Konversi & Keterangan \\
\hline 60 & 1 & 82,86 & 3,31 & $\mathrm{~B}+$ \\
80 & 10 & & & \\
100 & 3 & & & \\
Jumlah & 14 & & & \\
\hline
\end{tabular}

Merujuk pada Tabel 6, nilai terendah untuk formatif II adalah 60 dan tertinggi adalah 100. Satu siswa mendapat nilai di bawah kriteria ketuntasan atau ketuntasan klasikal adalah sebesar 92,86\%. Nilai ini berada di atas kriteria keberhasilan sehingga dapat dikatakan KBM siklus II berhasil memberi ketuntasan belajar dalam kelas. Nilai rata-rata kelas adalah 82,86. Data hasil formatif II ini disajikan pada Gambar 5.

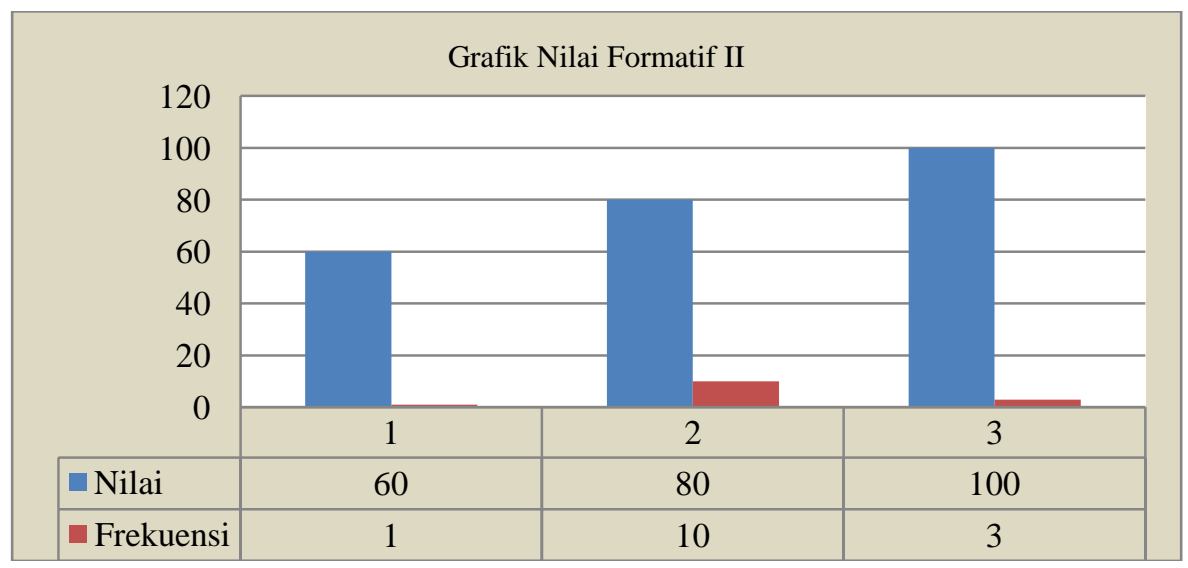

Gambar 5. Grafik Hasil Belajar Formatif II

Pada siklus II dilakukan pengamatan terhadap afektif siswa. Data afektif siswa pada siklus II disajikan pada Tabel 7.

Tabel 7. Afektif Belajar Siswa Siklus II

\begin{tabular}{clccc}
\hline No & \multicolumn{1}{c}{ Afektif } & Skor & Persentase & Kategori \\
\hline 1 & Kejujuran & 57 & $89 \%$ & $\mathrm{~A}$ \\
2 & Disiplin & 56 & $88 \%$ & $\mathrm{~A}$ \\
3 & Ketelitian & 56 & $88 \%$ & $\mathrm{~A}$ \\
4 & Saling Menghargai & 53 & $83 \%$ & $\mathrm{~B}$ \\
5 & Kerjasama & 53 & $83 \%$ & $\mathrm{~B}$ \\
& $\quad$ Rata-rata Proporsi & & $86 \%$ & $\mathrm{~A}$ \\
\hline
\end{tabular}

Dari data pada tabel 7 , kejujuran $89 \%$, disiplin $88 \%$, ketelitian $88 \%$, saling menghargai $88 \%$ dan kerjasama $83 \%$ dengan rata-rata proporsi pada siklus II sebesar 83\% yang berada dalam kategori nilai C. Data afektif siswa pada siklus II dapat disajikan dalam bentuk grafik pada gambar 6 . 


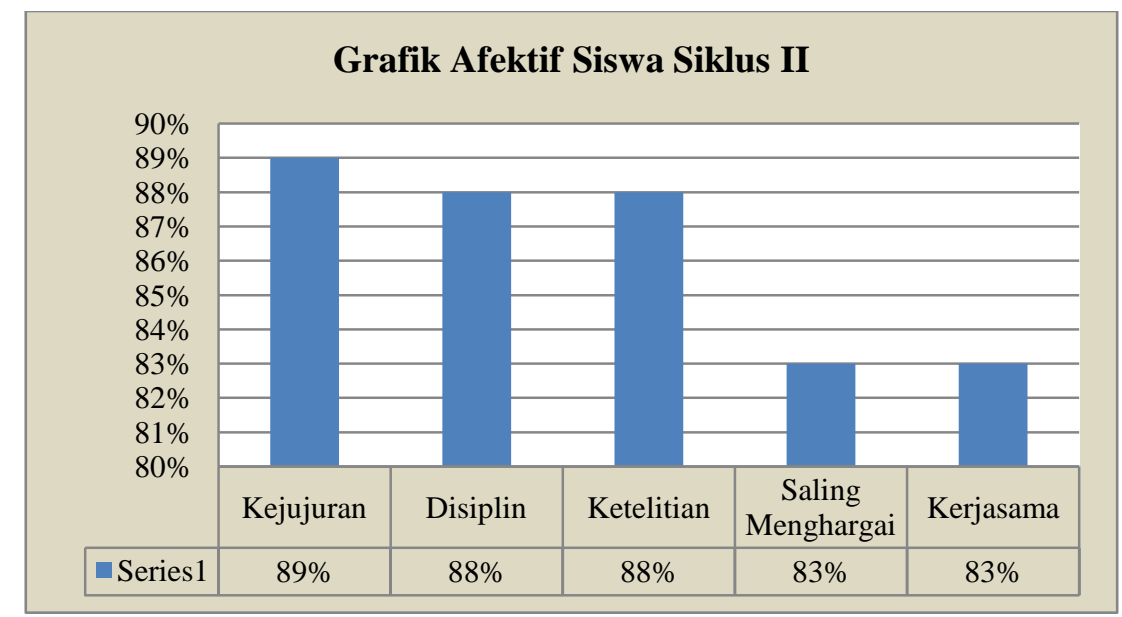

Gambar. 6 Grafik Afektif Belajar Siswa Siklus II

Data hasil observasi keterampilan belajar siswa selama siklus II disajikan pada Tabel 8 berikut:

Tabel 8 Psikomotorik Siklus II

\begin{tabular}{clccc}
\hline No & \multicolumn{1}{c}{ Psikomotorik } & Skor & Persentase & Kategori \\
\hline 1 & Mengamati & 59 & $92 \%$ & $\mathrm{~A}$ \\
2 & Menanya & 55 & $86 \%$ & $\mathrm{~A}$ \\
3 & Mengumpulkan Data & 57 & $89 \%$ & $\mathrm{~A}$ \\
4 & Mengasosiasi & 54 & $84 \%$ & $\mathrm{~B}$ \\
5 & Mengkomunikasikan Hasil & 53 & $83 \%$ & $\mathrm{~B}$ \\
& $\quad$ Rata-rata Proporsi & & $87 \%$ & $\mathrm{~A}$ \\
\hline
\end{tabular}

Pada tabel 8 terlihat jelas masih banyak siswa yang belum terampil dalam semua indikator. Keterampilan mengamati sebesar 92\%, menanya 86\%. Keterampilan mengumpulkan data sebesar $89 \%$ dan mengaosiasi sebesar $84 \%$. Dan yang terakhir keterampilan mengkomunikasikan hasil sebesar $83 \%$, dengan rata-rata proporsi psikomotorik siswa pada siklus II sebesar $74 \%$ yang berada dalam kategori nilai A. Data keterampilan siswa pada siklus II dapat disajikan pada histogram Gambar 7.

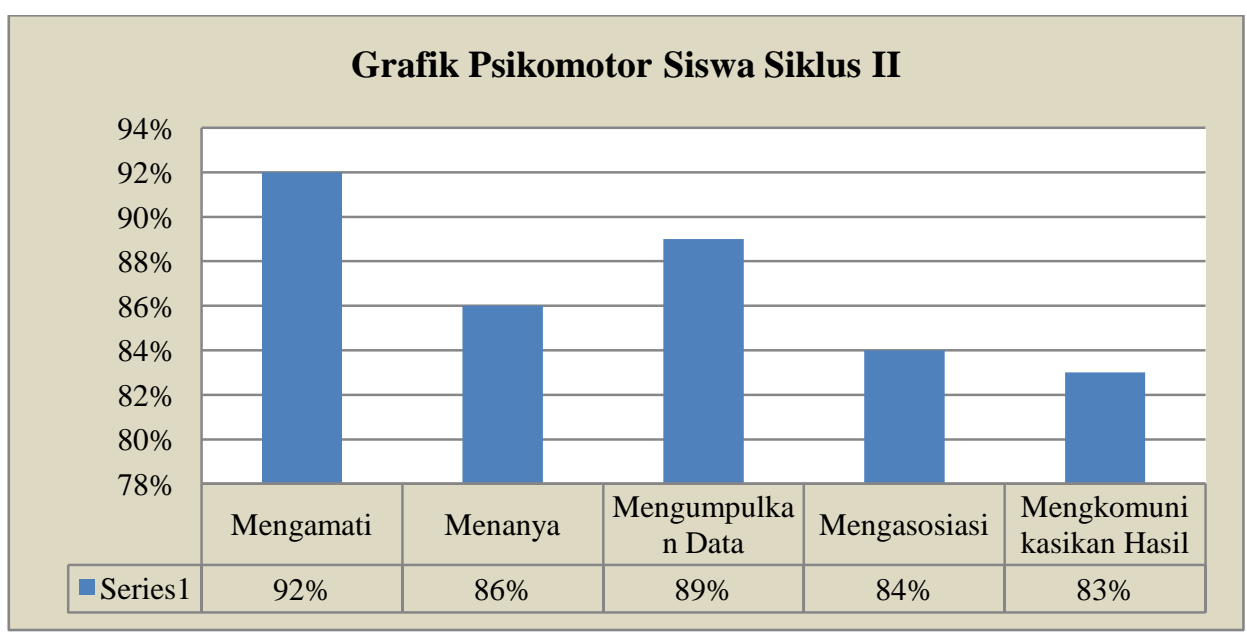

Gambar 7. Grafik Psikomotorik Siklus II 


\section{Refleksi dan Tahap Tindakan Perbaikan Pelaksanaan}

Selama pengamatan terhadap kegiatan siswa siklus II penilaian terhadap tes hasil belajar (ranah kognitif), dan pengamatan terhadap pelaksanaan penerapan pembelajaran dengan penerapan model pembelajaran kooperatif tipe Think-Pair-Share (TPS) padasiklus II, sudah tidak terlihat hal-hal yang cukup fatal yang harus diadakan perbaikan. Siswa sudah mulai aktif dalam diskusi maupun pada saat tanya jawab. Siklus II dapat diatasi oleh guru dengan baik, hasil belajar siswa sudah menunjukkan peningkatan dan semua siswa dikatakan tuntas. Secara keseluruhan semua aspek dalam hasil belajar mengalami peningkatan dari siklus I ke siklus II. Karena proses pelaksanaan pada siklus I dan siklus II telah dapat mencapai hasil yang diharapkan dan telah dapat menjawab rumusan masalah pada penelitian ini, maka tidak diadakan siklus selanjutnya. Sedangkan untuk revisi pelaksanaan, guru harus lebih pintar memanajemen waktu pada saat melakukan diskusi dan memberi sesi tanya jawab. Guru juga harus mampu memotivasi siswa agar siswa lebih aktif selama pembelajaran baik pembelajaran di sekolah, maupun pembelajaran di luar sekolah pada saat mengerjakan tugas yang diberikan oleh guru.

Sebelum pembelajaran siklus I dilakukan, telah disusun perangkat pembelajaran dan instrumen penelitian yang dihasilkan dari diskusi bersama tutor. Kemudian dilakukan tes hasil belajar sebagai pretes untuk mengetahui kondisi awal siswa. Nilai rata-rata kelas adalah 35,71 yang terendah untuk pretes adalah 30 dan tertinggi adalah 60 dengan KKM sebesar 70 tidak seorang pun mendapat nilai diatas ketuntasan atau ketuntasan klasikal adalah $0 \%$ yang mengindikasikan bahwa siswa tidak mempersiapkan diri dengan belajar di rumah tentang materi yang akan dibahas sebelum datang ke sekolah karena rendahnya minat dan aktivitas belajar siswa di sekolah maupun di rumah. Berdasarkan hasil data yang dikumpulkan, dapat dikemukakan dua hal pokok yang perlu diatasi, yaitu meningkatkan aktivitas yang bermuara pada peningkatan hasil belajar siswa pada mata pelajaran Agama Kristen dengan penerapan metode kooperatif tipe Think-Pair-Share.

Siklus I dilaksanakan dalam tiga kali pertemuan sesuai perencanaaan yang ditetapkan.Dapat ditarik kesimpulan bahwa kondisi pembelajaran siklus II yang relatif sama dengan siklus I ini berimplikasi pada hasil belajar kedua siklus yang tidak jauh berbeda. Setelah berakhirnya siklus I dilaksanakan, nilai rata-rata formatif I adalah 45,71 dimana nilai terendah formatif I adalah 20 dan tertinggi adalah 80 . Kriteria ketuntasan minimum yang ditetapkan adalah 70. Dari formatif yang dilakukan tersebut, 
ada 3 orang mendapat nilai diatas KKM, dengan demikian ketuntasan klasikal adalah sebesar 21,42\%. Kriteria ketuntasan klasikal yang ditetapkan adalah $85 \%$. Sehingga nilai ini tidak memenuhi kriteria keberhasilan. Dengan demikian dapat disimpulkan bahwa KBM siklus I tidak berhasil memberi ketuntasan belajar dalam kelas.

Berdasarkan pengamatan yang dilakukan pada Siklus I oleh peneliti dan observer (pengamat) di kelas selama proses KBM, maka dirumuskan beberapa kekurangan yang terjadi pada Siklus I, yaitu: (a) Siswa masih banyak yang bermainmain dalam diskusi kelompok pada KBM 1 dan KBM 2. Masih banyak siswa yang belum memahami perannya dalam kelompok; (b) Masih ada siswa yang kurang serius dalam belajar khususnya pada tahap think; (c) Masih banyak siswa yang kurang percaya diri sehingga mereka malu/takut membacakan hasil diskusinya di depan kelas; (d) Hasil belajar siswa pada siklus I belum mencapai ketuntasan meskipun terlihat ada perubahan hasil belajar siswa yang cukup signifikan; (e) Sulit apabila anggota pasangannya tidak aktif, maka akan mengakibatkan kelompok tersebut tidak aktif juga.

Pada Siklus I, guru telah menerapkan model pembelajaran kooperatif tipe ThinkPair-Share (TPS) dengan baik dan dilihat dari aktivitas siswa serta hasil belajar siswa pelaksanaan proses belajar mengajar sudah berjalan dengan baik. Memang masih diperlukan revisi, namun tidak terlalu banyak. Tetapi peneliti harus memperhatikan tindakan selanjutnya untuk memaksimalkan hasil yang telah ada dengan tujuan agar pada pelaksanaan proses belajar mengajar selanjutnya penerapan model pembelajaran kooperatif tipe Think-Pair-Share (TPS) dapat meningkatkan proses belajar mengajar sehingga tujuan pembelajaran dapat tercapai. Untuk meningkatkan proses pembelajaran dan aktivitas belajar siswa pada Siklus II, beberapa revisi pembelajaran dilakukan, yaitu: (a) Lebih memberikan motivasi kepada siswa agar bersedia melakukan kegiatan diskusi kelompok tanpa harus ditunjuk atau dibujuk agar aktivitas individual siswa menyusut dan meningkat aktivitas positif seperti mengerjakan LKS dan bertanya sesama teman; (b) Guru harus bertindak lebih tegas supaya siswa lebih tertib dalam mengikuti pelajaran dan siswa mau mengikuti setiap tahapan pembelajaran sesuai dengan model pembelajaran kooperatif tipe Think Pair Share. Kemudian, guru menjelaskan model belajar sesuai model pembelajaran kooperatif tipe Think Pair Share di awal pembelajaran, agar siswa mengerti dan mengikuti setiap tahapan dengan baik.

Setelah dilakukan perbaikan pembelajaran pada Siklus II berdasarkan hasil refleksi dan revisi siklus I maka pada Siklus II pembelajaran sudah mulai kondusif. Pada Siklus II, siswa yang diamati sebanyak 13 orang tuntas secara individu dan 1 
orang tidak tuntas secara individu. Merujuk pada Tabel 6, nilai terendah untuk formatif II adalah 60 dan tertinggi adalah 100 dengan kriteria ketuntasan minimal 70. Nilai ratarata yang diperoleh sebesar 82,86, nilai ini meningkat dibandingkaan formatif I dan telah tuntas. Sebanyak 13 siswa memperoleh nilai KKM atau ketuntasan klasikal telah mencapai 92,86\%. Mengacu pada kriteria ketuntasan klasikal minimum sebesar 85\%, maka nilai ini berada di atas kriteria keberhasilan sehingga dapat dikatakan KBM siklus II juga berhasil memberi ketuntasan belajar dalam kelas meski masih meninggalkan 1 siswa yang nilainya belum tuntas.

Perbaikan kualitas proses dan hasil belajar diperkuat dengan data observasi selama proses belajar siswa yang merujuk pada tentang afektif siswa, menunjukkan peningkatan kualitas pada afektif siswa dari siklus I ke siklus II. Rata-rata proporsi pada siklus I hanya $62 \%$ dengan kategori nilai D dan meningkat pada siklus II menjadi $86 \%$ dengan kategori nilai A. Hal ini telah memenuhi kriteria ketuntasan. Perbaikan proses pembelajaran tidak hanya pada aspek afektif. Dari aspek psikomotorik juga terjadi peningkatan dari siklus I ke siklus II. Nilai rata-rata psikomotorik proporsi pada siklus I adalah $63 \%$ dengan kategori nilai D dan meningkat pada Siklus II menjadi 87\% dengan kategori nilai A. Hal ini telah memenuhi kriteria ketuntasan.

\section{KESIMPULAN DAN SARAN}

Dari hasil kegiatan pembelajaran yang telah dilakukan sebanyak dua siklus dan berdasarkan seluruh pembahasan serta analisis yang telah dilakukan, dapat disimpulkan beberapa hal sebagai berikut: (1) Hasil belajar kognitif siswa meningkat sesuai dengan ketuntasan klasikal. Pada siklus I rata-rata nilai tes 45,71 dengan 3 siswa tuntas secara individu dan secara kelas belum tuntas. Pada siklus II rata-rata nilai tes 82,86 dengan 13 siswa tuntas secara individu dan secara kelas tuntas sehingga berhasil memberikan ketuntasan hasil belajar secara kelas; (2) Afektif siswa meningkat disetiap indikatornya dan sesuai dengan nilai rata-rata proporsi ketuntasan dengan nilai A (sangat baik). Peningkatan afektif siswa terjadi karena siswa terus dimotivasi dalam belajar sehingga siswa menunjukkan sikap yang positif; (3) Psikomotorik siswa meningkat disetiap indikatornya dan sesuai dengan nilai rata-rata proporsi ketuntasan dengan nilai $\mathrm{A}$ (sangat baik). Peningkatan psikomotorik siswa terjadi karena lingkungan belajar yang membantu siswa siswa untuk selalu mencoba mengumpulkan data, menganalisis, dan menginterpretasi, sehingga siswa terbiasa dengan proses belajarnya. 
Dari hasil penelitian yang diperoleh dari uraian sebelumnya agar proses belajar mengajar lebih efektif dan lebih memberikan hasil yang optimal bagi siswa, maka disampaikan saran, yaitu: (1) model pembelajaran kooperatif tipe Think-Pair-Share (TPS) dapat meningkatkan aktivitas dan hasil belajar siswa, oleh karena itu peneliti menyarankan guru-guru sejawat untuk menerapkan model pembelajaran ini selama pembelajaran; (3) untuk guru kelas secara khusus agar menerapkan model pembelajaran think-pair-share, dalam pembelajaran di kelas karena model ini dapat membantu siswa berpikir secara kritis; (3) bagi peneliti selanjutnya disarankan untuk mengganti soal instrumen dari pilihan berganda menjadi essay; (4) bagi guru disarankan menggunakan LKS setiap mengajar dengan model kooperatif karena hal ini dapat memfokuskan siswa dan membuat pembelajaran dengan kondusif.

\section{DAFTAR PUSTAKA}

Arikunto, S. (2002). Prosedur Penelitian Suatu Pendekatan Praktek. Jakarta:Rineksa Cipta.

Arikunto, S. (2002). Dasar-Dasar Evaluasi Pendidikan. Jakarta: Bumi Aksara.

Arikunto, S., \& Suhardjono, S. (2006). Penelitian Tindakan Kelas. Jakarta: PT.Bumi Aksara.

Hopkins, D. (1993). A Teacher's Guide to Classroom Research. Philadelphia. Open University Press

Nurnawati, E. (2012). Peningkatan Kerjasama Siswa SMP Melalui Penerapan Pembelajaran Kooperatif Pendekatan Think Pair Share. Unnes Physics Education Journal, 1(1), 1-7.

Purba, R. T. (2017). Implementasi Pendidikan Kristen Komunikatif di Sekolah Dasar Kristen: Sebuah Kajian Konseptual. Scriptura, 7(2), 57-62.

Sudjana, N. (2005). Metode Statistika. Bandung: Tarsito.

Suparno, P. (2007). Metodologi Pembelajaran Fisika Konstruktivistik dan Menyenangkan. Yogyakarta: Sanata Dharma. 